\title{
The Analysis of Intercultural Communication Competence in ESP Teaching ${ }^{1}$
}

\author{
LIU Xue-qing \\ Jiangsu Police Institute, Nanjing, China
}

\begin{abstract}
With the Belt and Road Initiative, the demand for Chinese college students to enhance their intercultural competence has been growing.Although the students' English proficiency has improved a lot, a large quantitative of students still have difficulties in communicating with people from different countries. With the development of present college education, China's college English teaching is undergoing a new phase of reformation because of various intrinsic or extrinsic factors.And most of the college students have been offered bilingual courses, EAP or ESP courses.More and more international activities have been held locally, and foreign exchanges and cooperation have become more frequent. From the perspective of the macroscopic social context, European countries have many common cultural origins, which are easy to express in the same or similar English; even if Asian countries and English-speaking countries have large cultural differences, the unique English expression is more common among different participants.By taking 120 undergraduates, graduates, and the post graduates as the sample, this paper is firstly trying to investigate the status quo through questionnaires and inquiries on the demand, the anticipation, expectation, and the relative strategies of intercultural communication skills nurturing in college English courses especially in ESP courses. The survey was conducted among students and graduates of our college, whose professional background and employment field are both the law enforcement and the policing, and most of them have volunteered in international activities or have the experience of international exchange. This paper is then through qualitative or quantitative analysis probing into the theoretical resources and practical nurturing practices of intercultural communication competence in ESP course from perspectives of objectives, activities, content, approaches of teaching, etc.And based on theories of communication, IC, ESP, teaching methods, etc., the thesis attempts to discuss the present problem or the insufficiency in IC teaching in ESP courses, and to provide several creative suggestions or strategies on how to change and improve the present situation.
\end{abstract}

Keywords: intercultural communication, ESP, the Belt and Road, cultural awareness, teaching approach

\section{Introduction}

With the Belt and Road Initiative, the demand for Chinese college students to enhance their intercultural

\footnotetext{
LIU Xue-qing, lecturer, the Teaching and Research Department of Fundamental Courses, Jiangsu Police Institute, Nanjing, China.

1 This paper is supported by Project for the Belt and Road Initiative-Oriented Language Ability Cultivation in the Police English Course in 2017 (No. 2017SJYWZ01), Provincial Project for the Cultivation of National Language Security Consciousness in the Perspective of English as the General Universal Language (2018SJA0448), and Project for Oral English Teaching and Evaluation Model of ESP Course Based on Modern Educational Technology-Taking Police English as the Viewpoint (QY105) from National Research Center. And this research has been also supported by the Brand Professional Construction Project Fund (TAPP) and by the Advantageous Subject Construction Project Fund (PAPD) for Universities in Jiangsu Province.
} 
competence has been growing. More and more international activities have been held locally, and foreign exchanges and cooperation have become more frequent. From the perspective of the macroscopic social context, European countries have many common cultural origins, which are easy to express in the same or similar English; even if Asian countries and English-speaking countries have large cultural differences, the unique English expression is more common among different participants.

Since the developing of present college education, China's college English teaching is undergoing a new phase of reformation because of various intrinsic or extrinsic factors. And most of the colleges have offered bilingual courses, EAP or ESP courses to students.

The cross-cultural education in foreign language teaching is a process in which the school determines course settings, teaching contents, and material selection through training objectives, and updates teaching philosophy, design teaching methods, teaching activities, and organic integration of school education and social practice. And it is a combination of personal values, identity, intercultural awareness, and competence.

Language, communication, and culture are the unity of a close connection. The process of foreign language teaching is the interactive process between the learner and other cultures and their respective related language-cultural dialogues. The ultimate goal of foreign language teaching is to cultivate students' intercultural competence.

This research tries to comprehensively understand and objectively evaluate the students' intercultural communicative competence and the current situation of cross-cultural teaching in our school's ESP curriculum through a range of questionnaires and interviews, and further analyzes the process of cultivating students' intercultural communicative competence and also what the teachers need to do to solve the problem.

\section{Method}

\section{Research Design and Participants}

Research objects. The research objects are all non-English majors from Jiangsu Police Institute, China. By taking 120 undergraduates, graduates, and the post graduates as the sample, this paper is firstly trying to investigate the status quo through questionnaires and inquiries on the demand, the anticipation, expectation, and the relative strategies of intercultural communication skills nurturing in college English courses especially in ESP courses. The survey was conducted among students and graduates of our college, whose professional background and employment field are both the law enforcement and the policing, and most of them have volunteered in international activities or have the experience of international exchange.

Subjects are all undergraduates, post graduates, and graduates from our school who have taken ESP courses, accounting for 50\%, 33.3\%, and $16.7 \%$, respectively. 15 of them have experience of being abroad and only four of the 15 are taking part in major-related study or work like peace keeping.

The following is the table about their graduation years:

Table 1

Years After Graduation of the Subjects

\begin{tabular}{llll}
\hline Years after graduations & $1-3$ & $4-8$ & 9 or more \\
\hline Number & 5 & 14 & 6 \\
\hline
\end{tabular}

Research methods. The research was firstly conducted through interviews. And the researchers conducted three group interviews and 20 individual interviews. Each interview takes 10-40 minutes. The core 
content of the interview is "your attitude about the role of English as a Common Language in intercultural communication of your volunteering in large-scale international security work", "Suggestions for developing cross-cultural communication skills in ESP Courses”, their daily study of English culture, and their intercultural communication experiences in international exchange. The questions interviewed towards the participants are most open-ended questions.

At the same time, in order to make sure the validity of the data analysis and to explore more deeply into the research, towards the chosen participants, a relevant research questionnaire is designed to collect information on nurturing cross-cultural communication competence, its teaching content, the curriculum setting, teaching methods, and other aspects of the evaluation in ESP courses and the subjects' evaluation, expectations, and suggestions for cross-cultural communication teaching in the ESP curriculum. The questionnaire is presented through the internet by social media. Respondents can fill in and send back online.

Table 2

The Language Level of the Objects and Their Experiences of Intercultural Communication

\begin{tabular}{lll}
\hline Language level & Number & Proportion \\
\hline CET4 (passed) & 117 & $91.4 \%$ \\
CET 4 (passed)_CET 6 (no passing) & 52 & $40.6 \%$ \\
CET 6/TEM 4 (passed) & 65 & $50.8 \%$ \\
Intermediate interpretation certificate & 5 & $0.04 \%$ \\
Senior interpretation certificate & 2 & $0.02 \%$ \\
Know a little second foreign language & 3 & $0.02 \%$ \\
Have the experience of intercultural communication & 106 & $82.8 \%$ \\
Have the experience working or studying abroad & 13 & $10.2 \%$ \\
Have the experience touring abroad & 90 & $70.3 \%$ \\
\hline
\end{tabular}

Table 3

The Categories of Intercultural Communication

\begin{tabular}{ll}
\hline Daily life vs. professional service & Person \\
\hline Daily life & 92 \\
Professional service & 78 \\
\hline
\end{tabular}

\section{Table 4}

Main Objects of Intercultural Communication, the Difficulties, and the Attitudes of IC

\begin{tabular}{|c|c|c|}
\hline Main objects & $\begin{array}{l}\text { Professional or } \\
\text { policing-concerned fields }\end{array}$ & $\begin{array}{l}\text { Main difficulty or } \\
\text { barriers in IC }\end{array}$ \\
\hline $\begin{array}{l}\text { People from English-speaking countries like UK, US, } 90 \\
\text { Canada, Australia }\end{array}$ & 55 & culture \\
\hline $\begin{array}{l}\text { People from countries where English are regarded as } \\
\text { official languages (like India, Singapore, etc.) }\end{array}$ & 58 & culture \\
\hline $\begin{array}{l}\text { People from non-English countries where English is } 93 \\
\text { only a foreign language }\end{array}$ & 97 & $\begin{array}{l}\text { culture, accent, } \\
\text { pronunciation }\end{array}$ \\
\hline People from areas or region along the R\&B 85 & 98 & \\
\hline
\end{tabular}


Table 5

IC-Related Categories in the Practical Policing

\begin{tabular}{lllllll}
\hline Categories & $\begin{array}{l}\text { Routine safety } \\
\text { guard }\end{array}$ & $\begin{array}{l}\text { Security inspection of } \\
\text { large-scale international } \\
\text { events }\end{array}$ & $\begin{array}{l}\text { Routine aliens } \\
\text { administration }\end{array}$ & $\begin{array}{l}\text { Traffic } \\
\text { administration }\end{array}$ & $\begin{array}{l}\text { Economic } \\
\text { cases-related }\end{array}$ & $\begin{array}{l}\text { Criminal } \\
\text { cases-related }\end{array}$ \\
\hline $\begin{array}{l}\text { Experience } \\
\begin{array}{l}\text { Feeling confident } \\
\text { or self-satisfied }\end{array}\end{array}$ & 20 & 117 & 38 & 9 & 45 & 42 \\
$\begin{array}{l}\text { Feeling frustrated } \\
\text { or dissatisfied }\end{array}$ & 5 & 85 & 25 & 4 & 32 & 28 \\
\hline
\end{tabular}

Table 6

The Attitudes and the Anticipation Towards IC Teaching in ESP

\begin{tabular}{|c|c|c|c|c|c|c|}
\hline No. & IC teaching in ESP & $\begin{array}{l}\text { Very } \\
\text { important }\end{array}$ & Important & Not sure & $\begin{array}{l}\text { Not very } \\
\text { important }\end{array}$ & $\begin{array}{l}\text { Not important } \\
\text { at all }\end{array}$ \\
\hline 1 & It is a necessary part in ESP teaching. & 105 & 8 & 3 & 4 & 0 \\
\hline 2 & $\begin{array}{l}\text { IC teaching should promote the understanding of } \\
\text { multi-cultural connotation besides the knowledge of } \\
\text { the profession. } \\
\text { ESP courses should not only carry out IC nurturing }\end{array}$ & 110 & 5 & 5 & 0 & 0 \\
\hline 3 & $\begin{array}{l}\text { from the classroom and teaching materials, but also } \\
\text { combine a variety of teaching resources and methods. } \\
\text { Help students acquire English communication skills }\end{array}$ & 106 & 4 & 0 & 0 & 0 \\
\hline 4 & $\begin{array}{l}\text { so that they can communicate with English speakers } \\
\text { in their future work or further studies. }\end{array}$ & 112 & 0 & 0 & 6 & 2 \\
\hline 5 & $\begin{array}{l}\text { Help students acquire English communication skills } \\
\text { so that they can communicate with English speakers } \\
\text { in their future work or further studies. }\end{array}$ & 110 & 5 & 0 & 2 & 3 \\
\hline 6 & $\begin{array}{l}\text { Enhance students' ability to survive and communicate } \\
\text { in an alien culture environment. }\end{array}$ & 100 & 8 & 2 & 5 & 5 \\
\hline 7 & $\begin{array}{l}\text { Help students improve their ability to deal with issues } \\
\text { arising from cross-cultural communication in their } \\
\text { work practices. }\end{array}$ & 105 & 5 & 4 & 3 & 0 \\
\hline 8 & $\begin{array}{l}\text { Intercultural communication skills can help in future } \\
\text { work further communication with English speakers. }\end{array}$ & 98 & 11 & 6 & 3 & 0 \\
\hline
\end{tabular}

Table 7

The Anticipation Towards IC Teaching in ESP

\begin{tabular}{|c|c|c|c|c|}
\hline No. & Concrete anticipations & For & Against & Rate \\
\hline 1 & $\begin{array}{l}\text { IC teaching in ESP courses should strengthen the correction of intonation of British and } \\
\text { American English. }\end{array}$ & 115 & 5 & 0 \\
\hline 2 & $\begin{array}{l}\text { IC teaching in ESP courses should pay attention to the removal of certain accent in } \\
\text { English. }\end{array}$ & 2 & 118 & 0 \\
\hline 3 & $\begin{array}{l}\text { IC teaching in ESP courses should pay attention to the flexible using of English, rather than } \\
\text { stylized. }\end{array}$ & 22 & 98 & 0 \\
\hline 4 & $\begin{array}{l}\text { IC teaching in ESP courses should pay more attention to the non-linguistic factors of } \\
\text { communication, such as communication strategies and professional knowledge. }\end{array}$ & 86 & 34 & 0 \\
\hline 5 & IC teaching in ESP courses should not pay too much attention to the form of language. & 109 & 11 & 0 \\
\hline 6 & $\begin{array}{l}\text { IC teaching in ESP courses needs to strengthen the cultural background knowledge of } \\
\text { Great Britain and America. }\end{array}$ & 102 & 18 & 0 \\
\hline 7 & $\begin{array}{l}\text { In addition to the interpretation of the British and American native language and culture, it } \\
\text { should also cover cultures of the neighboring countries, such as the countries along the Belt } \\
\text { and Road, such as countries in Southeast Asia, India, etc. }\end{array}$ & 112 & 8 & 0 \\
\hline
\end{tabular}


Table 8

IC Teaching Activities Carried Out in ESP Course

\begin{tabular}{|c|c|c|c|c|c|c|}
\hline No. & IC teaching activities carried out in ESP course & Always & Often & Sometimes & A little & Never \\
\hline 1 & $\begin{array}{l}\text { Supplementary explanation of the relevant IC-related content } \\
\text { of the textbook }\end{array}$ & 68 & 5 & 26 & 11 & 10 \\
\hline 2 & Oral discussion about student experience & 50 & 30 & 40 & 0 & 0 \\
\hline 3 & A written summary of student experience & 21 & 30 & 68 & 1 & 0 \\
\hline 4 & Let students tell about their own experience & 70 & 20 & 25 & 3 & 2 \\
\hline 5 & $\begin{array}{l}\text { Guide students to make comparison and discussion among } \\
\text { multi-culture through various forms }\end{array}$ & 26 & 30 & 60 & 2 & 2 \\
\hline 6 & $\begin{array}{l}\text { Teach students the related knowledge with a blended teaching } \\
\text { method such as MOOCs and micro lessons }\end{array}$ & 25 & 28 & 62 & 3 & 2 \\
\hline 7 & $\begin{array}{l}\text { Organize lectures to teach intercultural communication } \\
\text { strategies }\end{array}$ & 20 & 17 & 69 & 8 & 6 \\
\hline 8 & $\begin{array}{l}\text { Role playing to let students simulate intercultural } \\
\text { communication situations and present the appropriate way of } \\
\text { handling in real work }\end{array}$ & 17 & 16 & 78 & 5 & 4 \\
\hline
\end{tabular}

\section{Findings, Interpretations, and Recommendations}

From the above questionnaires and interview, it can be concluded that:

1. ESP teaching should focus on the cultivating of the students' language application ability, which should be based on cross-cultural awareness enhancing. And only by this way can the students be helped to achieve the ultimate goal of ESP learning-intercultural communication.

2. Through a variety of big data-driven modern educational technology and educational resources, students can develop intercultural communication awareness and intercultural communication skills.

3. Teachers can cultivate students' language security concept by using various off-campus practical resources and appropriate international communication platforms. The cultivation of the concept of language security cannot be achieved through classroom teaching and textbook knowledge instillation. On the one hand, teachers can provide practical opportunities and create simulation scenarios for teaching activities. With the increase of international exchanges, there is frequent international cooperation at all levels. These opportunities for intercultural communication can be used as a language security concept training situation. In these activities, students can not only improve their oral communication skills, but also truly feel the language security problems in intercultural communication.

4. Language is the carrier of culture, and thus the carrier of thought. It is of great importance to combine language, culture, and security together in ESP curriculum setting and to set reasonable and scientific teaching objectives, as well as the appropriate teaching content in ESP courses.

5. The curriculum system must take into account the norm nature or accuracy of language and the contemporary nature of the topic to discuss. Standard and appropriate performance enhances the confidence of learners in using language, and the contemporary performance of topics can arouse an effective interest in improving communication and thus contribute to the construction of learners' new cross-cultural knowledge systems.

It is important to acknowledge a limitation of this study. Due to the small number of the participants and the sole professional background of these participants, care should be taken in generalizing the findings of the research. 
In a word, the answer is beyond the scope of this research and calls for further research in the future.

\section{References}

Firth, A. (1996). The discursive accomplishment of normality on "lingua franca” English and conversational analysis. Journal of Pragmatics, 26, 237-259.

Gao, Y.-H., \& Xu, H.-C. (2015). World Englishes and China English research: Challenges and future directions of the new century. Journal of Xinjiang Normal University (Philosophy and Social Sciences), (5), 122-129.

Kachru, B. B. (Ed). (1982/1992). The other tongue: English cross cultures. Urbana and Chicago: University of Illinois Press.

Skehan, P. (1998). A cognitive approach to language learning. Oxford: Oxford University Press.

Seidlhofer, B. (2011). Understanding English as a lingua franca. Oxford: OUP.

Widdowson, H. (2015). Competence and capability: Rethinking the subject English. The Journal of Asia TEFL, 12, 1-17.

Xu, H.-C., \& Gao, Y.-H. (2014). On the attitudes of Chinese student volunteers towards world Englishes before and after 4 intercultural communication events. Foreign Language Education, (1), 43-48. 